\title{
Dormant Pruning Rehardening of Peach Pistils after a Winter Thaw
}

\section{Edward F. Durner \\ Rutgers Fruit Research Center, New Jersey Agricultural Experiment Station, Cook College, Rutgers University, RD 2 Box 38, Cream Ridge, NJ 08514}

\author{
Additional index words. Prunus persica, bud hardiness, ethephon, exotherms, deep \\ supercooling
}

In regions where substantial cold injury to peach flower buds occurs, pruning is delayed as long as possible before bloom to assess bud injury and adjust pruning severity accordingly (Chandler, 1925). Pruning is also delayed to reduce mortality from the peach tree short-life complex (Dowler, 1975). In dormant apple trees, pruning alters growthregulating substances (Grochowska et al., 1984). Such alterations, if they occur in peach, might induce flower bud growth, thus increasing susceptibility to low-temperature injury. A fall application of ethephon at 100 $\mathrm{mg} \cdot$ liter $^{-1}$ has been shown to increase hardiness of peach flower buds (Durner and Gianfagna, 1988), reduce flower bud growth (Gianfagna et rd., 1988), alter carbohydrate metabolism, retard pistil development (Durner, 1989), and reduce fruit size at harvest (Durner et al., 1990). At rates >100 $\mathrm{mg} \cdot \mathrm{liter}^{-1}$, lethal gummosis has been reported (Coston et al., 1985). The current study was initiated to investigate the effect of dormant pruning on deep supercooling of peach pistils and to determine if there are any interactions of fall-applied ethephon with dormant pruning.

Ethephon (100 mg.liter $\left.{ }^{-1}\right)$ was applied to runoff on 6-year-old peach trees [Prunus persica (L.) Batsch., CV. Jerseyglo] on 17 Oct. 1988 . Regulaid $(0.1 \% \mathrm{v} / \mathrm{v})$ was added to assist spreading and also was used alone as a control. Ethephon-treated and nontreated trees were pruned either on 4 Nov. or 6 Dec. 1988, 13 Jan. or 14 Feb. 1989; unpruned checks also were maintained. Pruning consisted of moderate removal of shoots with thinning-out cuts and an occasional bench cut to maintain tree shape. The experimental units were single trees of similar vigor in a completely random design with three replications. On 30 Nov. and 19 Dec. 1988, and 4 Jan., 4, 14, and 21 Feb., and 7 and 22 Mar. 1989, flower buds were sampled for exotherm analysis from unbranched terminal, shoots around the periphery of the

Received for publication 14 Aug. 1989. New Jersey Agricultural Experiment Station, Publication no. D-12111-13-89, supported by state funds. The technical assistance of Francis X. Rooney is greatly appreciated. The cost of publishing this paper was defrayed $\mathrm{m}$ part by the payment of page charges. Under postal regulations, this paper therefore must be hereby marked advertisement solely to indicate this fact. observations. canopy $1 \mathrm{~m}$ above the orchard floor. Nodes with two flower buds were excised from the stem with xylem tissue intact on a small portion of bark $\approx 1 \mathrm{~cm}$ long, Ten nodes per treatment combination were sampled on each date. Buds were adhered to thermoelectric modules (Melcor Materials Electronics Products, Trenton, N. J.) with a thermal conducting paste (Omegatherm 201, Omega Engineering, Stamford Corm.)(Andrews et al., 1983), placed in a Puffer Hubbard freezer equipped with a Honeywell cam programmer (Rheem Scientific, Asheville, N. C.) and equilibrated to $-1 \mathrm{C}$. Millivolt signals generated by the modules and reference temperatures were recorded on an Omega Datalogger. Exotherms were detected as sudden changes in millivolt generation in the time-temperature profiles. Ice nucleation was induced by first placing a $10-\mu l$ drop of ice water followed by snow crystals on one cut surface of the nodal xylem tissue. Nucleation was verified by the presence of high-temperature exotherms associated with nonlethal extracellular ice formation. Samples were then cooled at a rate of $2 \mathrm{C} / \mathrm{hr}$ to $-30 \mathrm{C}$. Data were subjected to an analysis of variance for an incomplete factorial using Type III sums of squares from the General Linear Models procedure of SAS (SAS Institute, Cary, N.C.). Mean low-temperature exotherms were separated using Fisher's protected LSD, $P=$ 0.05 .

A significant ethephon treatment $\times$ pruning date $\times$ sampling date interaction was detected. Neither pruning nor ethephon treatment influenced the mean low-temperature exotherm of peach pistils through January. Mean exotherms for 30 Nov., 19 Dec., and 4 Jan. were $-16.4,-18.2$, and $-18.5 \mathrm{C}$, respectively. Beginning 8:00 AM on 28 Jan. 1989, there were 136 consecutive hours of above-freezing temperatures with a maximum of $20 \mathrm{C}$ on 1 Feb. On 4 Feb., unpruned, ethephon-treated buds were hardier $(-18.7 \mathrm{C})$ than buds from any other treatment combination (average - 14.7C) (Table 1). Flower buds in all treatments, except untreated January-pruned trees, were able to reharden with the return of cold weather (Table 1). By March, no effect of pruning or ethephon treatment was detected. All samples had rehardened considerably with mean exotherm values of -15.9 and $-13.8 \mathrm{C}$ on 7 and 22 Mar., respectively.

This study indicates that pruning peach trees after rest completion (January) reduces flower bud hardiness by decreasing rehardening after a thaw. In unpruned trees, ethephon significantly reduced the amount of pistil rehardening during a post-rest thaw (28 Jan. to 4 Feb.), but did not prevent rehardening in pistils from pruned trees. Following the thaw, pistils from untreated, January-pruned trees did not reharden, while those from ethephontreated, January-pruned trees rehardened.

\section{Literature Cited}

Andrews, P. K., E.L. Proebsting, and G.S. Campbell. 1983. An exotherm sensor for measuring the cold hardiness of deep-supercooled flower buds by differential thermal analysis. HortScience 18:77-78.

Chandler, W.H. 1925. Fruit growing. Houghton Mifflin, New York.

Coston, D. C., G.W. Krewer, T.E. Elkner, J.G. Williamson, and E.T. Sims, Jr. 1985. Chemical treatments to delay bloom in peach. J. Amer. Soc. Hort. Sci. 110:874-877.

Dowler, W.M. 1975. Relationship between time of pruning and peach decline, p. 180-183. In: N.F. Childers (ed.). The peach. Horticultural Publications, New Brunswick, N.J.

Dumer, E.F. and T.J. Gianfagna. 1988. Fall ethephon application increases peach flower bud resistance to low-temperature stress. J. Amer. Soc. Hort. Sci. 113:404-406.

Dumer, E.F. 1989. Cryoprotection of reacclimating peach flower buds by ethephon alteration of pistil carbohydrate content. Cryobiology 26:290-296.

Durner, E. F., T.J. Gianfagna, F.X. Rooney, G.S. Teiger, M.J. Seiler, and M.J. Cantarella. 1990. Harvest date and size distribution of peach fruit are altered with fall-applied ethephon. HortScience 25(8):911-913.

Gianfagna, T. J., E.F. Durner, and G.S. Teiger. 1988. Reducing low temperature injury to peach flower buds with ethephon. Actsa Hort. 239:203206.

Grochowska, M. J., A. Karaszewska, B. Jankowska, J. Maksymiuk, and M.W. Williams. 1984. Dormant pruning influence on auxin, gibberellin, and cytokinin levels in apple trees. J. Amer. Soc. Hort Sci. 109:312-318.

Table 1. Mean low-temperature exotherms on three dates for peach flower buds from trees treated in the fall with $100 \mathrm{mg}$ ethephon/liter followed by dormant pruning on four dates.

\begin{tabular}{|c|c|c|c|c|c|c|}
\hline \multirow{3}{*}{$\begin{array}{l}\text { Pruning } \\
\text { date }\end{array}$} & \multicolumn{6}{|c|}{ Sampling date $^{z}$} \\
\hline & \multicolumn{2}{|c|}{4 Feb. } & \multicolumn{2}{|c|}{14 Feb. } & \multicolumn{2}{|c|}{$21 \mathrm{Feb}$. } \\
\hline & Control & Ethephon & Control & Ethephon & Control & Ethephon \\
\hline & \multicolumn{6}{|c|}{$\left({ }^{\circ} \mathrm{C}\right)$} \\
\hline Control & $-12.3 b$ & $-18.7 \mathrm{a}$ & $-18.7 \mathrm{a}$ & $-19.3 a$ & $-16.7 \mathrm{a}$ & $-16.3 a$ \\
\hline November & $-15.6 b$ & $-15.1 \mathrm{~b}$ & $-18.9 \mathrm{a}$ & $-19.3 \mathrm{a}$ & $-18.0 \mathrm{a}$ & $-18.3 a$ \\
\hline December & $-15.2 b$ & $-14.8 \mathrm{~b}$ & $-18.9 \mathrm{a}$ & $-19.0 \mathrm{a}$ & $-17.1 \mathrm{a}$ & $-17.6 \mathrm{a}$ \\
\hline January & $-14.7 b$ & $-14.9 b$ & $-17.0 \mathrm{~b}$ & $-19.0 \mathrm{a}$ & $-14.8 b$ & $-18.0 \mathrm{a}$ \\
\hline
\end{tabular}

${ }^{2}$ Mean separation within sampling date by Fisher's protected LSD, $P=0.05$. Values arc means of 20 